\title{
First Simultaneous Observations of Formaldehyde and Glyoxal by MAX-DOAS in the Indo-Gangetic Plain Region
}

\author{
Hossain Mohammed Syedul Hoque ${ }^{1}$, Hitoshi Irie ${ }^{1}$, Alessandro Damiani ${ }^{1}$, Prajjwal Rawat ${ }^{2}$, and Manish Naja ${ }^{2}$ \\ ${ }^{1}$ Center for Environmental Remote Sensing (CEReS), Chiba University, Japan \\ ${ }^{2}$ Aryabhatta Research Institute of Observational Sciences (ARIES), Nainital, India
}

\begin{abstract}
Since January 2017 continuous multi-axis differential optical absorption spectroscopy (MAX-DOAS) observations have been performed for the first time at Pantnagar $\left(29.03^{\circ} \mathrm{N}, 79.47^{\circ} \mathrm{E}\right)$, a semi-urban site located in the Indo-Gangetic Plain region in India. Here we report the formaldehyde ( $\mathrm{HCHO})$, glyoxal (CHOCHO), and nitrogen dioxide $\left(\mathrm{NO}_{2}\right)$ concentrations for the lowest layer $(0-1 \mathrm{~km})$ of the retrieved vertical profiles. The ratio of $\mathrm{CHOCHO}$ to $\mathrm{HCHO}$ concentrations $\left(R_{G F}\right)$, an important tracer indicative of changes in volatile organic compound emissions was estimated. During spring and autumn enhanced concentrations of $\mathrm{HCHO}$ and $\mathrm{CHOCHO}$ were observed under the influence of biomass burning. The mean $R_{G F}$ for the whole observation period (JanuaryNovember) in Pantnagar was estimated to be $0.029 \pm 0.006$. Comparing with similar MAX-DOAS observations in central Thailand and reported literature values, we found that the $R_{G F}$ tends to be $<\sim 0.04$ under the influence of biomass burning and/or anthropogenic emissions.
\end{abstract}

(Citation: Hoque, H. M. S., H. Irie, A. Damiani, P. Rawat, and M. Naja, 2018: First simultaneous observations of formaldehyde and glyoxal by MAX-DOAS in the Indo-Gangetic Plain region. SOLA, 14, 159-164, doi: 10.2151/sola.2018-028.)

\section{Introduction}

It has been well recognized that volatile organic carbons (VOCs) can change the oxidization capacity of the atmosphere, contribute to the formation of secondary organic aerosols and tropospheric ozone, and lead to the production of cloud condensation nuclei (Houweling et al. 1998; Liakakou et al. 2007; Monks 2005; Poisson et al. 2000; Volkamer et al. 2006). VOCs are emitted from oceans, vegetation, biomass burning, fossil fuel usage, and geochemical processes (Alvarado et al. 2014; Kansal 2009). Two important oxidized products of VOCs are formaldehyde (HCHO) and glyoxal (CHOCHO), which are thought to be useful tracers of VOC fluxes to the atmosphere (e.g., Hoque et al. 2018).

$\mathrm{HCHO}$ is the most abundant and simplest aldehyde in the atmosphere (Kansal 2009). It is predominantly a photochemical degradation product of methane and non-methane hydrocarbons (NMHCs) emitted from natural and anthropogenic sources (Fu et al. 2007; Jenkin et al. 1997). Primary sources of HCHO include direct emissions from biomass burning, industrial processes, fossil fuel combustion (Andreae and Merlet 2001; Lee et al. 1997; Holzinger et al. 1999; Yokelson et al. 1999; Geiger et al. 2002), and vegetation (Seco et al. 2007). The sinks of HCHO include photolysis, oxidization by hydroxyl $(\mathrm{OH})$ radicals, and wet deposition (Arlander et al. 1995).

$\mathrm{CHOCHO}$ is the smallest and one of the most prevalent dicarbonyl compounds in the atmosphere. The main source of $\mathrm{CHOCHO}$ is the oxidation of biogenic VOCs such as isoprene and terpenes followed by anthropogenic VOCs such as acetylene, benzene, toluene, and xylene (Fu et al. 2008; Myriokefalitakis et al. 2008). CHOCHO can also be formed during the use of biomass and biofuels (Fu et al. 2008). The sinks of CHOCHO are similar

Corresponding author: Syedul Hoque, CEReS, Chiba University, 1-33 Yayoi-Cho, Chiba 263-8522, Japan. E-mail: hoquesyedul@gmail.com. to those for $\mathrm{HCHO}$, i.e., photolysis reactions (Fu et al. 2008), reaction with $\mathrm{OH}$ radicals, and dry and wet depositions (Myriokefalitakis et al. 2008). In addition, reversible and irreversible uptakes of $\mathrm{CHOCHO}$ by aqueous aerosols were reported (Kroll et al. 2005; Galloway et al. 2009; Ervens and Volkamer et al. 2010).

Due to the similar sinks and sources of $\mathrm{HCHO}$ and $\mathrm{CHOCHO}$, the $\mathrm{CHOCHO}$ to $\mathrm{HCHO}$ concentration ratio $\left(R_{G F}\right)$ is considered to be a possible tracer of changes in VOC emission sources (e.g., Hoque et al. 2018). But discrepancies remain in studies reporting the response of $R_{G F}$ to different VOC emission sources. MacDonald et al (2012) conducted long-path differential optical absorption spectroscopy (DOAS) measurements of $\mathrm{HCHO}$ and $\mathrm{CHOCHO}$ in a tropical forest, and reported an $R_{G F}>0.2$. Using multi-axis DOAS (MAX-DOAS) measurements in Mainz, Ortega et al. (2015) observed $R_{G F}$ values lower than 0.04 at a site dominated by anthropogenic emissions. Using satellite observations, Vrekoussis et al. (2010) found that the $R_{G F}$ ranges between 0.04 and 0.06 in regions with strong biogenic emissions, whereas it can be below 0.03 in regions influenced by anthropogenic emissions. In contrast, DiGangi et al. (2012) conducted in-situ measurements of HCHO and $\mathrm{CHOCHO}$ during two observation campaigns in Pinus Ponderosa forests and found higher $R_{G F}$ from anthropogenic reactive VOC mixtures and biomass burning compared with biogenic reactive VOC mixtures. Kaiser et al. (2015) observed higher $R_{G F}$ over areas with strong monoterpene emissions and attributed lower $R_{G F}$ to strong isoprene emissions during an aircraft campaign over the southeastern U.S. Thus, the $R_{G F}$ response to different types of VOC emissions sources is yet under discussion. Here, we report almost one-year (January 2017 to November 2017) MAX-DOAS observations of $\mathrm{HCHO}$ and $\mathrm{CHOCHO}$ at Pantnagar, India (29.03 ${ }^{\circ} \mathrm{N}, 79.47^{\circ} \mathrm{E}, 237$ m.a.s.1). Besides, estimating the $R_{G F}$, we compare the $R_{G F}$ response with the result from similar MAX-DOAS observations at a rural site in central Thailand (Hoque et al. 2018).

\section{Observation site and methodology}

The Indo-Gangetic Plain (IGP) is one of the most populated regions in the world. Pantnagar is a semi-urban site situated in the IGP region in India. It is located $\sim 225 \mathrm{~km}$ northeast of the capital city New Delhi (Fig. 1). The Himalayan mountains lie in the north and east direction of the site, while low altitude plains are situated in the south and west. The major roadway connecting Pantnagar to nearby cities and a small local airport $(\sim 3 \mathrm{~km})$ are situated close to the site. Few small-scale industries are located in Rudrapur $(\sim 12$ $\mathrm{km}$ southwest of Pantnagar) and Haldwani ( $25 \mathrm{~km}$ northeast of Pantnagar). The climate in Pantnagar is divided into four seasons: (1) winter (December to February), (2) spring (March to May), (3) summer monsoon (June to August), and (4) autumn (September to November).

A MAX-DOAS instrument similar to the one used by Hoque et al. (2018) for observations at Phimai, Thailand was installed in a building at Biotech Bhavan, Haldi in Pantnagar and its continuous observation started on 17 January 2017. The MAX-DOAS instrument measures ultraviolet-visible (UV-VIS) spectra of scattered sunlight at different elevation angles (ELs). The detailed description of the instrument is provided elsewhere (Irie et al. 2011, 2015; Hoque et al. 2018). The EL sequence of $3^{\circ}, 4^{\circ}, 5^{\circ}, 6^{\circ}$, $8^{\circ}$, and $70^{\circ}$ was used, and the same sequence of ELs was repeated 


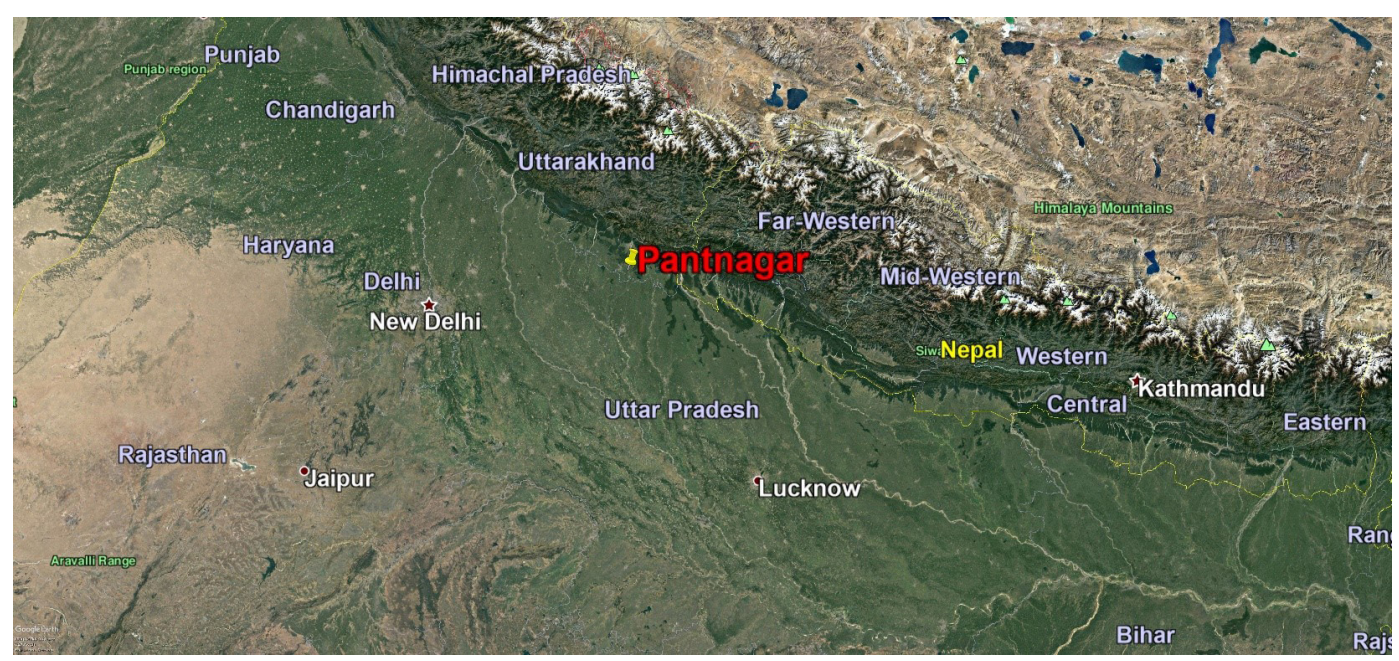

Fig. 1. Location of Pantnagar which is situated $\sim 225 \mathrm{~km}$ northeast of New Delhi. The map has been produced using the Google Earth application.

every $15 \mathrm{~min}$. To minimize the possible systematic error in oxygen collision complex $\left(\mathrm{O}_{4}\right)$, MAX-DOAS off-axis EL measurements were limited to below $10^{\circ}$, while the measurement sensitivity in the lowest layer was kept maximum (Irie et al. 2015). The spectra between 310 and $515 \mathrm{~nm}$ were recorded. The wavelength calibration was performed using a high-resolution solar spectrum from Kurucz et al. (1984). The spectral resolution (full width at half maximum) was about $0.4 \mathrm{~nm}$ at 357 and $476 \mathrm{~nm}$. Measured spectra were analyzed using the Japanese vertical profile retrieval algorithm version 2 (JM2) (Irie et al. 2011, 2015). The retrieval procedures and error estimates are described in detail by Irie et al. (2008a, 2008b, 2011, 2015). A short description is provided here.

First, the measured spectra were analyzed utilizing the DOAS technique (Platt 1994) to retrieve the differential slant column density $(\triangle \mathrm{SCD})$ of trace gases. $\triangle \mathrm{SCD}$ is defined as the difference between the spectral measurement at an EL and that at the reference $\mathrm{EL}$ at $70^{\circ}$. $\mathrm{HCHO}$ and $\mathrm{CHOCHO} \triangle \mathrm{SCD}$ values were retrieved from fitting windows of 336-359 and 436-457 nm, respectively. The closest fitting windows containing significant $\mathrm{O}_{4}$ absorptions around 360 and $477 \mathrm{~nm}$ were utilized to retrieve the $\mathrm{O}_{4} \Delta \mathrm{SCD}$ values (Irie et al. 2009, 2011). The absorption cross-section data used and the absorbers fitted in the HCHO and CHOCHO fitting windows are identical to those used by Hoque et al. (2018).

Following the DOAS analysis, the retrieved $\mathrm{O}_{4} \Delta \mathrm{SCD}$ values were converted to aerosol optical depth (AOD) and vertical profiles of aerosol extinction coefficient, using the aerosol retrieval algorithm based on optimal estimation (Irie et al. 2008a; Rodgers 2000). The radiative transfer model JACOSPAR (Irie et al. 2015) was used to create a lookup table (LUT) for the box air mass factor $\left(A_{b o x}\right)$ vertical profile, which is defined as the ratio of the slant to vertical columns for a given layer. JACOSPAR is based on the Monte Carlo Atmospheric Radiative Transfer Simulator (MCARaTS) (Iwabuchi 2006). The results of MCARaTS have been validated against other radiative transfer models (Wagner et al. 2007). Utilizing the $A_{b o x}$ LUT, the optimal aerosol loading and the $A_{b o x}$ profiles which corresponds to the $\mathrm{O}_{4} \Delta \mathrm{SCD}$ values at all ELs, were determined. Thus, this is different from simple geometric calculations. Following the similar procedure as the aerosol retrieval, $\mathrm{HCHO}$ and $\mathrm{CHOCHO} \triangle \mathrm{SCD}$ values were converted to their vertical column densities (VCDs) and vertical profiles of $\mathrm{HCHO}$ and $\mathrm{CHOCHO}$, respectively. The $A_{b o x}$ profiles in the LUT were calculated for 357 and $476 \mathrm{~nm}$, which were slightly different from the trace gas wavelengths. To address such wavelength differences, the AOD at the desired trace gas wavelength was estimated from the retrieved AOD at the closer aerosol wavelength, assuming an Ångström exponent of unity. Then, the recalculated AOD was used to select the corresponding $A_{b o x}$ profiles from the
Table 1. Estimated errors (\%) for the retrieved $\mathrm{CHOCHO}$ and $\mathrm{HCHO}$ VMRs for the $0-1-\mathrm{km}$ layer.

\begin{tabular}{ccccc}
\hline Component & Total error & Random error & $\begin{array}{c}\text { Systematic } \\
\text { error }\end{array}$ & $\begin{array}{c}\text { Error due to } \\
\text { bias in EL }\end{array}$ \\
\hline CHOCHO & 25 & 14 & 20 & 5 \\
HCHO & 37 & 20 & 31 & 5 \\
\hline
\end{tabular}

\section{LUT.}

The estimated total error consisted of random and systematic components. The random error was estimated from the residuals that arose from the fittings of the HCHO (or CHOCHO) $\triangle \mathrm{SCD}$. The systematic error was estimated assuming changes in the retrieved AOD (corresponding $A_{b o x}$ values), with values as high as 50 and $30 \%$, respectively (Irie et al. 2011). The estimated errors, including the uncertainty in the ELs, are summarized in Table 1. To minimize the impact of clouds, retrievals for retrieved AOD greater than 3, corresponding to the highest value in the LUT, were excluded. These are likely due mostly to optically thick clouds. Further data screening was performed based on residuals of the $\mathrm{O}_{4} \Delta \mathrm{SCD}(<10 \%)$, CHOCHO $\triangle \mathrm{SCD}(<50 \%)$, HCHO $\triangle \mathrm{SCD}(<50 \%)$, and the degree of freedom of the signal greater than 1.02 .

\section{Results and discussion}

To characterize $\mathrm{HCHO}$ and $\mathrm{CHOCHO}$ data (at 0600-1800 local time (LT)) for the $0-1 \mathrm{~km}$ layer retrieved by MAX-DOAS at Pantnagar for 2017, their seasonal variations are shown in Fig. 2. Significant enhancements of both HCHO ( $\sim 6 \mathrm{ppbv})$ and CHOCHO ( $\sim 0.2 \mathrm{ppbv})$ concentrations were observed during spring and autumn. While biomass burning activities vary with geographical locations within India, they are usually predominant in spring (Venkataraman et al. 2006). Significant biomass burning activities during spring and autumn in Pantnagar and its nearby areas have been also reported (Kumar et al. 2011; Bhardwaj et al. 2016). To confirm them, the daily and monthly mean fire radiative power (FRP) data within $100 \mathrm{~km}$ of Pantnagar were analyzed (Fig. 2c). FRP is a measure of outgoing radiant heat from fires (Justice et al. 2002). The data were obtained from the MODIS Active Fire Detections data website (https://firms.modaps.eosdis.nasa.gov). Most of the fires were observed during spring and autumn, in correspondence to enhancements in $\mathrm{HCHO}$ and $\mathrm{CHOCHO}$. In Fig. 2d, MAX-DOAS retrieved HCHO data are also shown together 


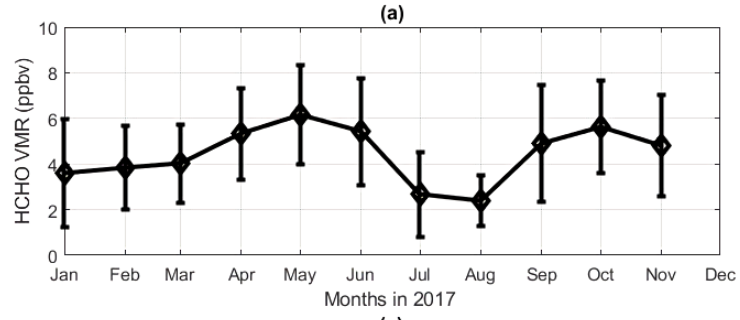

(c)

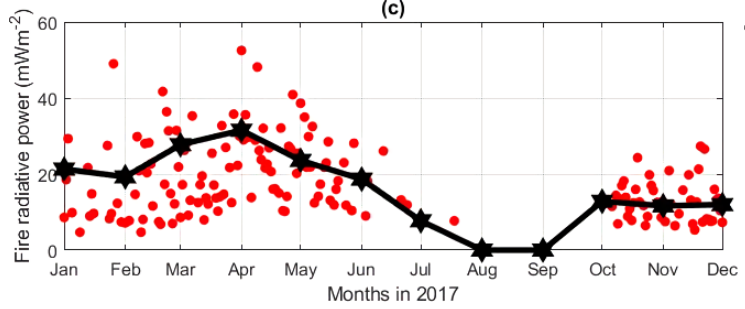

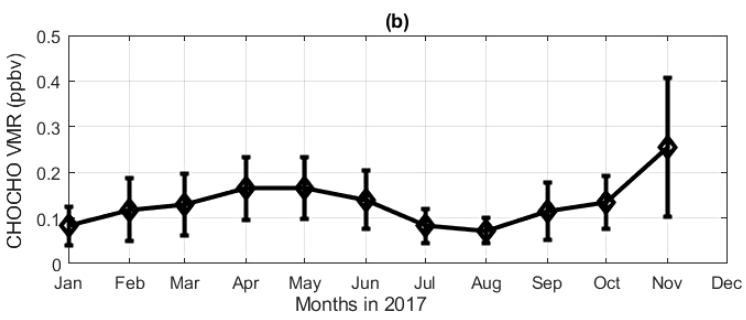

(d)

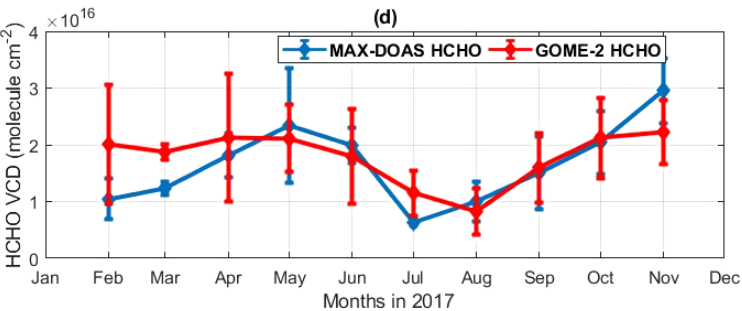

Fig. 2. Time series of monthly means of (a) HCHO and (b) CHOCHO VMRs for the 0-1 km layer retrieved from the MAX-DOAS observations in Pantnagar in 2017 . The error bars represent the $1 \sigma$ standard deviation of the data used to calculate the monthly mean. HCHO and CHOCHO observations from 0600-1800 LT were used to calculate the monthly mean. (c) Daily and monthly mean fire radiative power (FRP) averaged over a distance of 100 km centred at Pantnagar. The black line and red dots indicate monthly and daily mean FRP values, respectively. (d) Comparison between HCHO time series obtained from our MAX-DOAS measuements and GOME-2 observations. GOME-2 observations were averaged over a distance of 50 km centred at Pantnagar. Data with cloud fraction $(\mathrm{CF})<0.2$ were used. The monthly means were calculated using days in common between GOME-2 and morning MAX-DOAS (0900-1100 LT) data. The error bars represents the $1 \sigma$ of the data used to calculate monthly means.

(a)

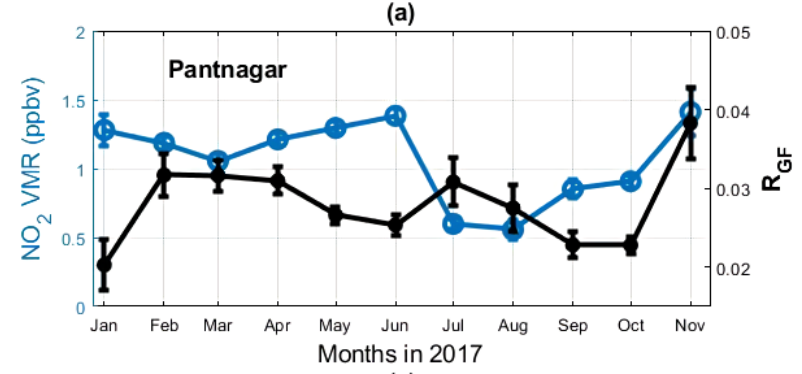

(c)

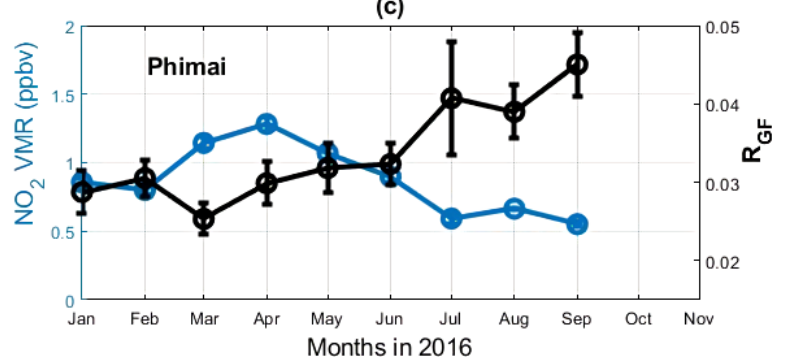

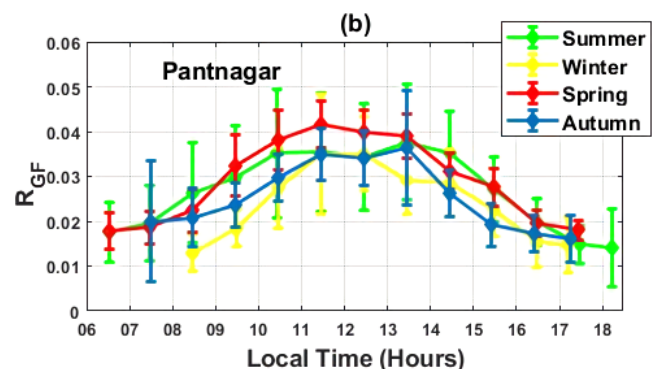

(d)

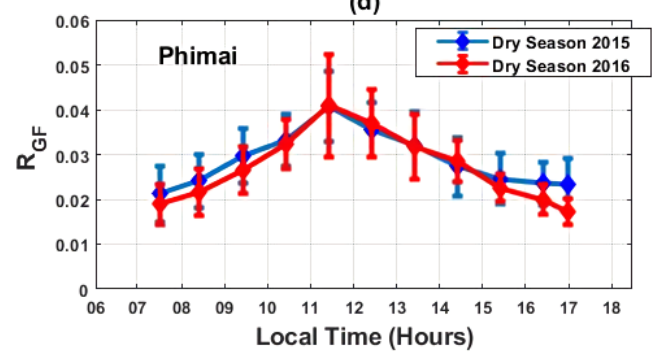

Fig. 3. (a) Time series of monthly mean $\mathrm{NO}_{2}$ VMRs for the $0-1 \mathrm{~km}$ layer and the estimated monthly mean $R_{G F}$ values in Pantnagar. Observations from 0600-1800 LT were used to calculate the monthly means. (b) Diurnal variation of $R_{G F}$ in Pantnagr during different seasons. (c) Time series of monthly mean $\mathrm{NO}_{2}$ VMRs for the 0-1 km layer and the estimated monthly mean $R_{G F}$ values for the dry (January-April) and wet season (June-September) in Phimai in 2016. Observations from 0700-1700 LT were used to calculate the monthly mean. (d) Diurnal variation of $R_{G F}$ in Phimai during the dry season (JanuaryApril) in 2015 and 2016. The error bars in (a), (b), (c), and (d) show the $2 \sigma$ standard error.

with those from the GOME-2 satellite observational product, published by the German Aerospace Centre (Hassinen et al. 2016). The overpass time of GOME-2 at the equator is 0930 LT. The days in common between GOME-2 and morning MAX-DOAS (0900-1100 LT) data were used to calculate the monthly averages. GOME-2 data were averaged within $50 \mathrm{~km}$. Good positive correlation $(R=0.71)$ between the observations was found. The enhancements of HCHO during the spring and autumn were also seen in the satellite observations. These correspondences support the potential link between biomass burning activities in IGP and the observed enhancement of both $\mathrm{HCHO}$ and $\mathrm{CHOCHO}$.

The mean $R_{G F}$ for the whole observation period was estimated to be $0.029 \pm 0.006$. The daily mean CHOCHO and HCHO VMRs for the $0-1-\mathrm{km}$ layer were used for the estimation. The uncertainty was estimated following the procedure of Hoque et al. (2018). The estimated $R_{G F}$ for the Pantnagar site was in the range of values reported in literatures for different conditions of VOC emission sources (Munger et al. 1995; Grosjean et al. 1996; Possanzini et al. 2007; Choi et al. 2010; Irie et al. 2011; DiGangi et al. 2012; Kaiser et al. 2015). For detailed understanding of the change in $R_{G F}$ at Pantnagar, $R_{G F}$ values for different seasons were estimated (Fig. 3a). $R_{G F}$ values at Pantnagar were found to have varied between $\sim 0.020$ and $\sim 0.039$. Utilizing satellite measurements, Vrekoussis et al. (2010) reported high $R_{G F}$ values $(0.04-0.06)$ where dominant VOC sources were biogenic, whereas $R_{G F}$ values $(<0.03)$ were lower for regions with enhanced $\mathrm{NO}_{2}$ level. Moreover, Kaiser 
et al. (2015) also observed a high $R_{G F}(0.04-0.07)$ under strong biogenic VOC emissions. The Pantnagar site can be influenced by biomass burning during the spring and autumn. The seasonal variation in $\mathrm{NO}_{2}$, which was retrieved simultaneously with $\mathrm{HCHO}$ and $\mathrm{CHOCHO}$ using JM2 utilizing the fitting window of 460-490 $\mathrm{nm}$, showed enhanced $\mathrm{NO}_{2}$ concentrations during spring and autumn (Fig. 3a). Biomass burning can contribute to the high $\mathrm{NO}_{2}$ observed over the IGP region during spring and autumn (Ghude et al. 2013). Fu et al. (2007) found significant contribution of biomass burning to the observed HCHO variability over India during spring. However, based on our dataset, it is hard to assess the relative contribution of anthropogenic and pyrogenic sources in Pantnagar. Thus, the lower $R_{G F}$ during spring and autumn could be potentially due to the combined influence of anthropogenic emissions and biomass burning. Although IGP is known as a high vegetation area (Mahajan et al. 2015), lower correlation among temperature, $\mathrm{HCHO}$, and $\mathrm{CHOCHO}$ were observed in Pantnagar (Fig. S1). Seasonal variation in normalized difference vegetation index (NDVI) and enhanced vegetation index (EVI) were also poorly correlated with $\mathrm{HCHO}$ and $\mathrm{CHOCHO}$ (Fig. S2). Over strong vegetation areas, Vrekoussis et al. (2010) found positive correlations among EVI, HCHO, and CHOCHO. With lower correlations among temperature, $\mathrm{HCHO}, \mathrm{CHOCHO}, \mathrm{NDVI}$, and EVI, biogenic emission sources can potentially be less significant in Pantnagar. Thus, the overall $R_{G F}(<0.04)$ observed in Pantnagar is likely mainly due to strong influence from biomass burning and anthropogenic emissions.

Figure $3 \mathrm{~b}$ shows the diurnal variation in $R_{G F}$ at Pantnagar. No significant differences in the diurnal $R_{G F}$ values were observed in different seasons and most of the time the values were less than $\sim 0.04$. Figure $3 \mathrm{~d}$ shows the diurnal variation in $R_{G F}$ estimated (0-1 km layer) from MAX-DOAS observations of HCHO and CHOCHO at Phimai $\left(15.18^{\circ} \mathrm{N}, 102.56^{\circ} \mathrm{E}\right)$, a rural site in Thailand (Hoque et al. 2018). Pronounced biomass burning occurred during the dry season (January-April) in Phimai (Sugimoto et al. 2015; Hoque et al. 2018). The $R_{G F}$ values in Phimai during dry seasons were mostly lower than 0.03 . The estimated mean $R_{G F}$ values during the dry seasons in Phimai and during all seasons in Pantnagar were similar (Table 2). Comparing the $R_{G F}$ values at both sites, it is observed that, under the influence of biomass burning and anthropogenic emissions $R_{G F}$ values tend to be $<\sim 0.04$. DiGangi et al. (2012) reported $R_{G F}$ value $\sim 0.03$ during a biomass burning event. The average $R_{G F}$ reported by Zarzana et al. (2017) from agricultural biomass burning was $\sim 0.038$, although the observed $R_{G F}$ had a wide range from 0.008 to 0.11 . The mean $R_{G F}$ values $<0.04$ for region associated with anthropogenic emissions
Table 2. Estimated $R G F$ during seasons influenced by biomass burning in Phimai and Pantnagar. The errors represent the $2 \sigma$ standard error.

\begin{tabular}{lc}
\hline \multicolumn{1}{c}{ Season and site } & $R_{G F}$ \\
\hline Winter (JF), Pantnagar & $0.029 \pm 0.003$ \\
Spring 2017 (MAM), Pantnagar & $0.030 \pm 0.002$ \\
Summer Monsoon (JJA), Pantnagar & $0.030 \pm 0.004$ \\
Autumn 2017 (SON), Pantnagar & $0.026 \pm 0.002$ \\
Dry Season 2015 (JFMA), Phimai & $0.030 \pm 0.001$ \\
Dry Season 2016 (JFMA), Phimai & $0.028 \pm 0.002$ \\
\hline
\end{tabular}

were also observed by Ortega et al. (2015) and Miller et al. (2014). Thus, under the influence of biomass burning and anthropogenic emissions, the mean $R_{G F}$ value tend to be less than $\sim 0.04$. However, $R_{G F}$ under the influence of biomass burning can vary with the type of biomass fuel (Akagi et al. 2013; Stcokwell et al. 2014). At both sites, crop waste was the main biomass fuel. Different crop residue types can also yield different $R_{G F}$ values (Kyle Zarzana, personal communication). If biomass burning was the dominant VOC source during spring and autumn in Pantanagar, then $R_{G F}$ $<0.04$ could potentially be representative of crop residues as biomass fuel. A detail classification of the biomass fuels, burning conditions, and VOC sources in Pantnagar is required to draw more definitive conclusion.

The correlation between $\mathrm{NO}_{2}$ and $R_{G F}$ for Pantnagar was not as strong that for Phimai (Fig. 3a). Figure 4 shows the correlation of $\mathrm{HCHO}$ and $\mathrm{CHOCHO}$ concentrations against $\mathrm{NO}_{2}$ for both sites. For Phimai, a rural site, the only significant $\mathrm{NO}_{2}$ source was most likely biomass burning, whereas Pantanagar can be influenced by local, regional, vehicular emissions, and biomass burning. This might lead to different correlations observed among the trace gases at both sites. Modeling studies by Li et al. (2014) suggested higher sensitivity of $R_{G F}$ to lower $\mathrm{NO}_{2}$ concentration. Kaiser et al. (2015) found no significant impact of $\mathrm{NO}_{\mathrm{x}}$ on $R_{G F}$ over urban areas. The overall $\mathrm{NO}_{\mathrm{x}}$ emissions in IGP are higher even within India (Ghude et al. 2008; Ojha et al. 2012), whereas the Phimai site is characterized by low $\mathrm{NO}_{2}(<1 \mathrm{ppbv})$ environment. Thus, the higher $\mathrm{NO}_{2}$ concentrations in Pantanagar could be a probable reason of the $R_{G F}$ response becoming less sensitive to the $\mathrm{NO}_{2}$. To understand the relative contribution of different VOC sources to the $R_{G F}$ value in Pantnagar, detailed characterization of relative VOC sources is required, which will be addressed in our future study. (a)

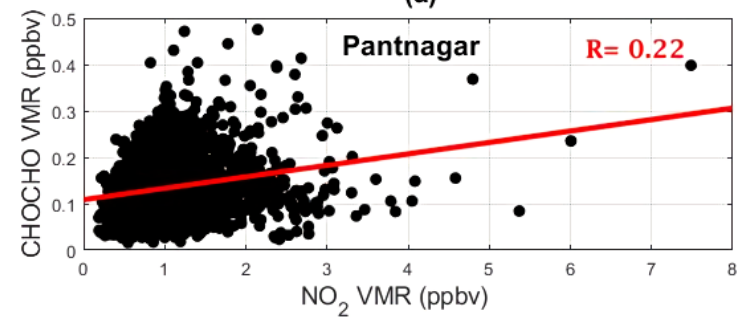

(c)

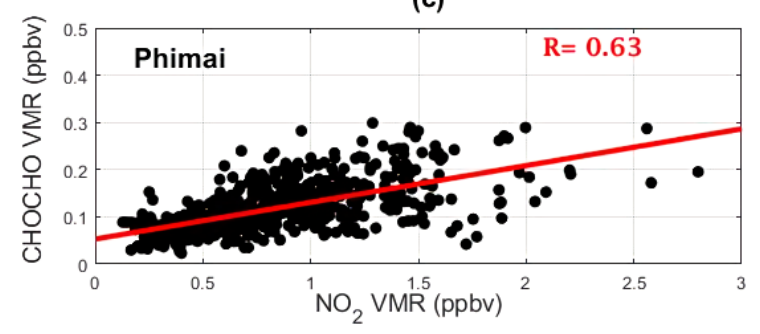

(b)

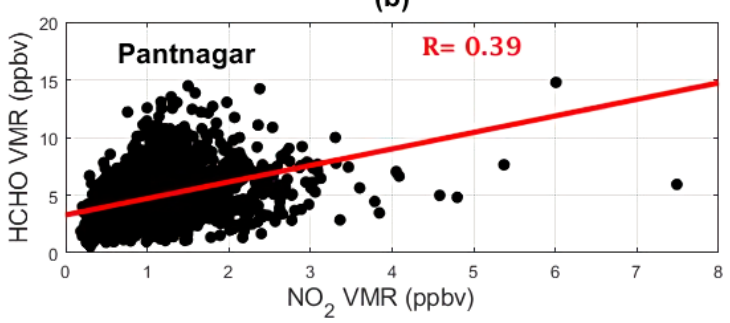

(d)

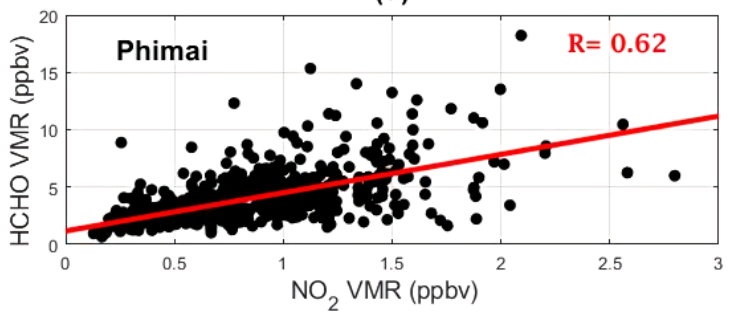

Fig. 4. Correlation among $\mathrm{NO}_{2}, \mathrm{HCHO}$, and CHOCHO at Pantnagar ((a) and (b)) and Phimai ((c) and (d)). The daily mean values are used for the correlation plots. Data for the whole observation period at both sites are included in the plots. 


\section{Conclusions}

We reported simultaneous MAX-DOAS observations of $\mathrm{HCHO}, \mathrm{CHOCHO}$, and $\mathrm{NO}_{2}$ conducted for the first time at a semi-urban site situated in the IGP region in India. The highest concentration of $\mathrm{HCHO}(\sim 6 \mathrm{ppbv})$ and $\mathrm{CHOCHO}(\sim 0.2 \mathrm{ppbv})$ were observed during spring and autumn. The monthly mean $\mathrm{NO}_{2}$ was less than $1.5 \mathrm{ppbv}$. Such enhancements were potentially due mainly to biomass burning activities. The estimated $R_{G F}$ for the Pantnagar site was $0.029 \pm 0.006$. Estimated $R_{G F}$ values for different seasons in Pantnagar were $<0.04$. The comparison with similar MAX-DOAS observations at a rural site in central Thailand and few reported literatures showed that under the influence of biomass burning and anthropogenic emission the $R_{G F}$ tends to be $<\sim 0.04$. The low correlation of NDVI and EVI with HCHO and $\mathrm{CHOCHO}$ was also suggestive of less significance of the biogenic VOC emission sources compared to biomass burning and anthropogenic emission sources.

\section{Acknowledgements}

The authors thank the AC SAF project of the EUMETSAT for providing satellite products used in this paper. We are thankful to the Director, Biotech Bhavan, Haldi, Director of ARIES and ISRO-ATCTM project for supporting this work. Technical support from Mr. Nitin (ARIES) is highly appreciated.

Edited by: Y. Miyazaki

\section{References}

Akagi, S. K., R. J. Yokelson, C. Wiedinmyer, M. J. Alvarado, J. S. Reid, T. Karl, J. D. Crounse, and P. O. Wennberg, 2011: Emission factors for open and domestic biomass burning for use in atmospheric models. Atmos. Chem. Phys., 11, 4039-4072.

Alvarado, L. M. A., A. Richter, M. Vrekoussis, F. Wittrock, A. Hilboll, S. F. Schreier, and J. P. Burrows, 2014: An improved glyoxal retrieval from OMI measurements. Atmos. Meas. Tech., 7, 4133.

Andreae, M. O., and P. Merlet, 2001: Emission of trace gases and aerosols from biomass burning. Global Biogeochem. Cycles, 15, 955-966.

Arlander, D., D. Brüning, U. Schmidt, and D. Ehhalt, 1995: The tropospheric distribution of formaldehyde during TROPOZ II. J. Atmos. Chem., 22, 251-269.

Bhardwaj, P., M. Naja, R. Kumar, and H. C. Chandola, 2016: Seasonal, interannual and long-term variabilities in biomass burning activity over South Asia. Environ. Sci. Pollut. Res., 23, 4397-4410.

Choi, W., I. Faloona, N. Bouvier-Brown, M. McKay, A. Goldstein, J. Mao, W. Brune, B. LaFranchi, R. Cohen, and G. Wolfe, 2010: Observations of elevated formaldehyde over a forest canopy suggest missing sources from rapid oxidation of arboreal hydrocarbons. Atmos. Chem. Phys., 10, 8761-8781.

DiGangi, J., S. Henry, A. Kammrath, E. Boyle, L. Kaser, R. Schnitzhofer, M. Graus, A. Turnipseed, J. Park, R. Weber, R. S. Hornbrook, C. A. Cantrell, R. L. Maudlin III, S. Kim, Y. Nakashima, G. M. Wolfe, Y. Kajii, E. Apel, A. H. Goldstein, A. Guenther, T. Karl, A. Hansel, and F. N. Keutsch, 2012: Observations of glyoxal and formaldehyde as metrics for the anthropogenic impact on rural photochemistry. Atmos. Chem. Phys., 12, 9529-9543.

Ervens, B., and R. Volkamer, 2010: Glyoxal processing by aerosol multiphase chemistry: Towards a kinetic modeling framework of secondary organic aerosol formation in aqueous particles. Atmos. Chem. Phys., 10, 8219-8244.

Fu, T.-M., D. J. Jacob, P. I. Palmer, K. Chance, Y. X. Wang, B. Barletta, D. R. Blake, J. C. Stanton, and M. J. Pilling, 2007: Space-based formaldehyde measurements as constraints on volatile organic compound emissions in east and south Asia and implications for ozone. J. Geophys. Res., 112, D06312.

Fu, T., D. Jacob, F. Wittrock, J. P. Burrows, M. Vrekoussis, and D. Henze, 2008: Global budgets of atmospheric glyoxal and methylglyoxal, and implications for formation of secondary organic aerosols. J. Geophys. Res., 113, D15303

Galloway, M. M., P. S. Chhabra, A. W. H. Chan, J. D. Surratt, R. C. Flagan, J. H. Seinfeld, and F. N. Keutsch, 2009: Glyoxal uptake on ammonium sulphate seed aerosol: Reaction products and reversibility of uptake under dark and irradiated conditions. Atmos. Chem. Phys., 9, 3331-3345.

Geiger, H., J. Kleffmann, and P. Wiesen, 2002: Smog chamber studies on the influence of diesel exhaust on photosmog formation. Atmos. Environ., 36, 1737-1747.

Ghude, S. D., S. Fadnavis, G. Beig, S. D. Polade, and R. J. van der A, 2008: Detection of surface emission hot spots, trends, and seasonal cycle from satellite retrieved $\mathrm{NO}_{2}$ over India. $J$. Geophys. Res., 113, D20305, doi:10.1029/2007JD009615.

Ghude, S. D., S. H. Kulkarni, C. Jena, G. G. Pfister, G. Beig, S. Fadnavis, and R. J. van der A, 2013: Application of satellite observations for identifying regions of dominant sources of nitrogen oxides over the Indian Subcontinent. J. Geophys. Res., 118, 1075-1089.

Grosjean, E., D. Grosjean, M. P. Fraser, and G. R. Cass, 1996: Air quality model evaluation data for organics. 2. C1-C14 carbonyls in Los Angeles air. Environ. Sci. Technol., 30, 2687-2703.

Hassinen, S., D. Balis, H. Bauer, M. Begoin, A. Delcloo, K. Eleftheratos, S. Gimeno Garcia, J. Granville, M. Grossi, N. Hao, P. Hedelt, F. Hendrick, M. Hess, K.-P. Heue, J. Hovila, H. Jonch-Sorensen, N. Kalakoski, A. Kauppi, S. Kiemle, L. Kins, M. E. Koukouli, J. Kujanpaa, J.-C. Lambert, R. Lang, C. Lerot, D. Loyola, M. Pedergnana, G. Pinardi, F. Romahn, M. van Roozendael, R. Lutz, I. De Smedt, P. Stammes, W. Steinbrecht, J. Tamminen, N. Thyes, L. G. Tilstra, O. N. E. Tunder, P. Valks, C. Zerefos, W. Zimmer, and I. Zyrichidou, 2016: Overview of the O3M SAF GOME-2 operational atmospheric composition and UV radiation data products and data availability. Atmos. Meas. Tech., 9, 383-407.

Holzinger, R., C. Warneke, A. Hansel, A. Jordan, W. Lindinger, D. H. Scharffe, G. Schade, and P. J. Crutzen, 1999: Biomass burning as a source of formaldehyde, acetaldehyde, methanol, acetone, acetonitrile, and hydrogen cyanide. Geophys. Res. Lett., 26, 1161-1164.

Hoque, H. M. S., H. Irie, and A. Damiani, 2018: First MAXDOAS obseravtions of formaldehyde and glyoxal in Phimai, Thailand. J. Geophys. Res., 123, 9957-9975.

Houweling, S., F. Dentener, and J. Lelieveld, 1998: The impact of nonmethane hydrocarbon compounds on tropospheric photochemistry. J. Geophys. Res., 103, 10673-10696.

Irie, H., Y. Kanaya, H. Akimoto, H. Iwabuchi, A. Shimizu, and K. Aoki, 2008a: First retrieval of tropospheric aerosol profiles using MAX-DOAS and comparison with lidar and sky radiometer measurements. Atmos. Chem. Phys., 8, 341-350.

Irie, H., Y. Kanaya, H. Akimoto, H. Tanimoto, Z. Wang, J. Gleason, and E. Bucsela, 2008b: Validation of OMI tropospheric $\mathrm{NO}_{2}$ column data using MAX-DOAS measurements deep inside the North China Plain in June 2006: Mount Tai Experiment 2006. Atmos. Chem. Phys., 8, 6577-6586.

Irie, H., Y. Kanaya, H. Akimoto, H. Iwabuchi, A. Shimizu, and K. Aoki, 2009: Dual-wavelength aerosol vertical profile measurements by MAX-DOAS at Tsukuba, Japan. Atmos. Chem. Phys., 9, 2741-2749.

Irie, H., H. Takashima, Y. Kanaya, K. Boersma, L. Gast, F. Wittrock, D. Brunner, Y. Zhou, and M. V. Roozendael, 2011: Eight-component retrievals from ground-based MAXDOAS observations. Atmos. Meas. Tech., 4, 1027-1044.

Irie, H., T. Nakayama, A. Shimizu, A. Yamazaki, T. Nagai, A. Uchiyama, Y. Zaizen, S. Kagamitani, and Y. Matsumi, 2015: Evaluation of MAX-DOAS aerosol retrievals by coincident observations using CRDS, lidar, and sky radiometer in Tsukuba, Japan. Atmos. Meas. Tech., 8, 2775-2788. 
Iwabuchi, H., 2006: Efficient Monte Carlo methods for radiative transfer modeling. J. Atmos. Sci., 63, 2324-2339.

Jenkin, M. E., S. M. Saunders, and M. J. Pilling, 1997: The tropospheric degradation of volatile organic compounds: A protocol for mechanism development. Atmos. Environ., 31, 81-104.

Justice, C. O., L. Giglio, S. Korontzi, J. Owens, J. T. Morisette, D. P. Roy, J. Descloitres, S. Alleaume, F. Petitcolin, and Y. Kaufman, 2002: The MODIS fire products. Remote Sens. Environ., 83, 244-262.

Kaiser, J., G. M. Wolfe, K. E. Min, S. S. Brown, C. C. Miller, D. J. Jacob, J. A. deGouw, M. Graus, T. F. Hanisco, J. Holloway, J. Peischl, I. B. Pollack, T. B. Ryerson, C. Warkene, R. A. Washenfelder, and F. N. Keutsch, 2015: Reassessing the ratio of glyoxal to formaldehyde as an indicator of hydrocarbon precursor speciation. Atmos. Chem. Phys., 15, $7571-7583$.

Kansal, A., 2009: Sources and reactivity of NMHCs and VOCs in the atmosphere: A review. J. Hazard. Mater., 166, 17-26.

Kroll, J. H., N. L. Ng, S. M. Murphy, V. Varutbangkul, R. C. Flagan, and J. H. Seinfeld, 2005: Chamber studies of secondary organic aerosol growth by reactive uptake of simple carbonyl compounds. J. Geophys. Res., 110, D23207.

Kumar, R., M. Naja, S. K. Satheesh, N. Ojha, H. Joshi, T. Sarangi, P. Pant, U. C. Dumka, P. Hegde, and S. Venkataramani, 2011: Influences of the springtime northern Indian biomass burning over the central Himalayas. J. Geophys. Res., 116, D19302.

Kurucz, R., I. Furenlid, J. Brault, and L. Testerman, 1984: Solar Flux Atlas from 296 to 1300 nm. Natl. Sol. Obs., Sunspot, New Mexico, 240.

Lee, D., I. Köhler, E. Grobler, F. Rohrer, R. Sausen, L. GallardoKlenner, J. Olivier, F. Dentener, and A. Bouwman, 1997: Estimations of global NO, emissions and their uncertainties. Atmos. Environ., 31, 1735-1749.

Li, X., F. Rohrer, T. Brauers, A. Hofzumahaus, K. Lu, M. Shao, Y. H. Zhang, and A. Wahner, 2014: Modelling of HCHO and $\mathrm{CHOCHO}$ at a semi-rural site in southern China during the PRIDE-PRD2006 campaign. Atmos. Chem. Phys., 14, 12291-12305.

Liakakou, E., M. Vrekoussis, B. Bonsang, C. Donousis, M. Kanakidou, and N. Mihalopoulos, 2007: Isoprene above the Eastern Mediterranean: Seasonal variation and contribution to the oxidation capacity of the atmosphere. Atmos. Environ., 41, 1002-1010.

MacDonald, S. M., H. Oetjen, A. S. Mahajan, L. K. Whalley, P. M. Edwards, D. E. Heard, C. E. Jones, and J. C. Plane, 2012: DOAS measurements of formaldehyde and glyoxal above a south-east Asian tropical rainforest. Atmos. Chem. Phys., 12, 5949-5962.

Mahajan, A. S., I. De Smedt, M. S. Biswas, S. D. Ghude, S. Fadnavis, C. Roy, and M. van Roozendael, 2015: Interannual variations in satellite observations of nitrogen dioxide and formaldehyde over India. Atmos. Environ., 116, 194-201.

Miller, C., G. Gonzalez Abad, H. Wang, X. Liu, T. Kurosu, D. J. Jacob, and K. V. Chance, 2014: Glyoxal retrieval from the ozone monitoring instrument. Atmos. Meas. Tech., doi: 10.5194/amt-7-3891-2014.

Monks, P. S., 2005: Gas-phase radical chemistry in the troposphere. Chem. Soc. Rev., 376-395.

Munger, J. W., D. J. Jacob, B. C. Daube, L. Horowitz, W. Keene, and B. Heikes, 1995: Formaldehyde, glyoxal, and methylglyoxal in air and cloudwater at a rural mountain site in central Virginia. J. Geophys. Res., 100, 9325-9333.

Myriokefalitakis, S., M. Vrekoussis, K. Tsigaridis, F. Wittrock, A. Richter, C. Brühl, R. Volkamer, J. P. Burrows, and M. Kanakidou, 2008: The influence of natural and anthropogenic secondary sources on the glyoxal global distribution. Atmos. Chem. Phys., 8, 4965-4981.

Ojha, N., M. Naja, K. P. Singh, T. Sarangi, R. Kumar, S. Lal, M. G. Lawrence, T. M. Butler, and H. C. Chandola, 2012: Variabilities in ozone at a semi-urban site in the Indo-Gangetic
Plain region: Association with the meteorology and regional processes. J. Geophys. Res., 117, D20301.

Ortega, I., T. Koenig, R. Sinreich, D. Thomson, and R. Volkamer, 2015: The CU 2-D-MAX-DOAS instrument-Part 1: Retrieval of 3-D distributions of $\mathrm{NO}_{2}$ and azimuth-dependent OVOC ratios. Atmos. Meas. Tech., 8, 2371-2395.

Platt, U. (Ed.), 1994: Differential Optical Absorption Spectroscopy (DOAS), Chemical Analysis Series, Wiley \& Sons. Inc., 27-84.

Poisson, N., M. Kanakidou, and P. J. Crutzen, 2000: Impact of non-methane hydrocarbons on tropospheric chemistry and the oxidizing power of the global troposphere: 3-dimensional modelling results. J. Atmos. Chem., 36, 157-230, doi:10.1023/A:1006300616544.

Possanzini, M., G. Tagliacozzo, and A. Cecinato, 2007: Ambient levels and sources of lower carbonyls at Montelibretti, Rome (Italy). Water Air Soil Poll., 183, 447-454.

Rodgers, C. D., 2000: Inverse Methods for Atmospheric Sounding: Theory and Practice, World scientific Singapore.

Seco, R., J. Peñuelas, and L. Filella, 2007: Short-chain oxygenated VOCs: Emission and uptake by plants and atmospheric sources, sinks, and concentrations. Atmos. Environ., 41, 2477-2499.

Sugimoto, N., A. Shimizu, T. Nishizawa, I. Matsui, Y. Jin, P. Khatri, H. Irie, T. Takamura, K. Aoki, and B. Thana, 2015: Aerosol characteristics in Phimai, Thailand determined by continuous observation with a polarization sensitive MieRaman lidar and a sky radiometer. Environ. Res. Lett., 10, 065003

Stockwell, C. E., P. R. Veres, J. Williams, and R. J. Yokelson, 2015: Characterization of biomass burning emissions from cooking fires, peat, crop residue, and other fuels with high-resolution proton-transfer-reaction time-of-flight mass spectrometry. Atmos. Chem. Phys., 15, 845-865.

Venkataraman, C., G. Habib, D. Kadamba, M. Shrivastava, J. F. Leon, B. Crouzille, O. Boucher, and D. G. Streets, 2006: Emissions from open biomass burning in India: Integrating the inventory approach with high resolution Moderate Resolution Imaging Spectroradiometer (MODIS) active fire and land cover data. Global Biogeochem. Cycles, 20, GB2013.

Volkamer, R., J. L. Jimenez, F. San Martini, K. Dzepina, Q. Zhang, D. Salcedo, L. T. Molina, D. R. Worsnop, and M. J. Molina, 2006: Secondary organic aerosol formation from anthropogenic air pollution: Rapid and higher than expected. Geophys. Res. Lett., 33, L17811.

Vrekoussis, M., F. Wittrock, A. Richter, and J. P. Burrows, 2010; GOME-2 observations of oxygenated VOCs: What can we learn from the ratio glyoxal to formaldehyde on a global scale? Atmos. Chem. Phys., 10, 10145-10160.

Wagner, T., J. P. Burrows, T. Deutschmann, B. Dix, C. v. Friedeburg, U. Frieß, F. Hendrick, K.-P. Heue, H. Irie, and H. Iwabuchi, 2007: Comparison of box-air-mass-factors and radiances for Multiple-Axis Differential Optical Absorption Spectroscopy (MAX-DOAS) geometries calculated from different UV/visible radiative transfer models. Atmos. Chem. Phys., 7, 1809-1833.

Yokelson, R. J., J. G. Goode, D. E. Ward, R. A. Susott, R. E. Babbitt, D. D. Wade, I. Bertschi, D. W. Griffith, and W. M. Hao, 1999: Emissions of formaldehyde, acetic acid, methanol, and other trace gases from biomass fires in North Carolina measured by airborne Fourier transform infrared spectroscopy. J. Geophys. Res., 104, 30109-30125.

Zarzana, K. J., K. Min, R. A. Washenfelder, J. Kaiser, M. Krawiec-Thayer, J. Peischl, J. A. Neuman, J. B. Nowak, N. L. Wagner, W. P. Dubè, J. M. Clair, G. M. Wolfe, T. H. Hanisco, F. N. Keutsch, T. B. Ryerson, and S. S. Brown, 2017: Emissions of Glyoxal and Other Carbonyl Compounds from Agricultural Biomass Burning Plumes Sampled by Aircraft. Environ. Sci. Technol., 51, 11761-11770.

Manuscript received 5 July 2018, accepted 27 September 2018 SOLA: https://www.jstage.jst.go.jp/browse/sola/ 